\title{
アルミニウムアノード酸化皮膜を基板とした光触媒膜の高活性化
}

\author{
藤野 隆由 ${ }^{*} \cdot$ 服部 貴則 $* *$
}

Journal of Japan Institute of Light Metals, Vol. 56, No. 4 (2006), pp. 197-202

\section{Activation of photocatalytic coatings applied on aluminum oxidation film}

\author{
Takayoshi FUJINO* and Takanori HATTORI**
}

\begin{abstract}
Aluminum was anodized in a $\mathrm{H}_{2} \mathrm{SO}_{4}$ solution, and then platinum and tin were electrodeposited into nano-pores of anodic oxidation film in $\mathrm{H}_{2} \mathrm{PtCl}_{6}$ and $\mathrm{SnSO}_{4}$ solutions. Titanium (IV) oxide $\left(\mathrm{TiO}_{2}\right)$ thin film was immobilized on electrolytically colored anodic oxide coating of aluminum. The photocatalytic activity of prepared films was analyzed for photolysis of the malachite green. In the results, the photocatalytic activity of $\mathrm{Pt}$ loaded $\mathrm{TiO}_{2}\left(\mathrm{TiO}_{2} / \mathrm{Pt} / \mathrm{Al}_{2} \mathrm{O}_{3}\right)$ film was highest in all films, and the relation between the amount of metallic colloid and photocatalytic activity was confirmed. Photocatalytic activity improved with electrodeposition increases, and activity was highest when the amount of platinum was about $3.1 \mu \mathrm{gcm}^{-2}$. But photocatalytic activity began to decline when the amount of platinum exceeded $3.1 \mu \mathrm{gcm}^{-2}$ because the platinum had a recombination center and decreasing surface area by electrodeposition. The photocatalytic activity of $\mathrm{Sn}$ loaded $\mathrm{TiO}_{2}\left(\mathrm{TiO}_{2} / \mathrm{Sn} / \mathrm{Al}_{2} \mathrm{O}_{3}\right)$ film didn't reach the $\mathrm{TiO}_{2} / \mathrm{Pt} / \mathrm{Al}_{2} \mathrm{O}_{3}$ film, indicating photocatalytic activity of about 1.8 times compared with $\mathrm{TiO}_{2} / \mathrm{Al}_{2} \mathrm{O}_{3}$ film. $\mathrm{SnO}_{2}$ manifested photocatalysis as well as $\mathrm{TiO}_{2}$, confirming that sintered tin was $\mathrm{SnO}_{2}$ in the results of ESCA. Therefore, anodic oxidation film and electrolytically colored anodic oxide coating were effective substrates of photocatalyst films.
\end{abstract}

(Received July 25, 2005 Accepted November 18, 2005)

Keywords: photocatalyst, anodic oxidation, aluminum, platinum

\section{1. 緒言}

アルミニゥム材は軽量で加工性がよく, しかもリサイクル が容易なため様々な分野で活用されているが，硬度が低く， 両性金属であるため酸にもアルカリにも溶解し，耐食性，耐 薬品性等に問題がある。しかし, 表面処理性は高く, アノー ド酸化やめっき，化成処理などの表面処理を施し，硬度や耐 食性を向上させることで耐久性を要する部位に用いることが できる。近年，表面処理分野において高硬度，高耐食性以外 の機能が求められるようになり，本来皮膜が保持していない 磁性や光触媒活性, 強誘電性等の機能性を付加させる研究が 盛んに行われている(1) 6)。中でも光触媒は, 殺菌や防污, 有 害物質の分解等の作用があることで知られており，その用途 は多様でェネルギー源も光のみであることから環境にも優し く, 精力的に研究が行われている7 ${ }^{70)}$ 。代表的な光触媒之し ては, 酸化チタン $\left(\mathrm{TiO}_{2}\right)$, 酸化すず $\left(\mathrm{SnO}_{2}\right)$, 酸化亜鉛 ( $\mathrm{ZnO})$ なよ゙が挙げられるが, 特に, 酸化チタンは光触媒活 性, 化学的安定性, 無害性や比較的可視光に近い光で励起す るなどといった様々な特徵から広く研究対象之されており, また報告例屯多い。光触媒活性は表面積や結晶性，不純物な ど様々なファクタに左右されうるため, 板上に固定化する際 には，基板の影響も大きく受ける。アノード酸化によって作 製された皮膜の表面には非常に微細な孔が存在するため非常 に大きな表面積を有しており, 光触媒膜の基板としたとき,
処理を施していない基板に比べてより高い活性を示す。さら に種々の金属塩溶液中で電解することにより細孔中に金属を 電析させることができるため, これを基板とすることで金属 担持之同様の効果を得られると考えられる。光触媒に金属が 担持されると，光を照射したときに励起した電子が担持金属 に集中することで電子 - 正孔対の電荷分離が効率的に起こ り, 酸化・還元反応が表面において起こりやすくなるだけで なく電子－正孔の再結合を抑制することができる。また，電 子を吸着酸素またはプロトンに供与しやすくなることにより， 還元反応が高効率化するために光触媒活性が向上すると考元 られる。したがって本研究では, 上り活性の高い光触媒膜基 板の作製を目的とした。アルミニウム板を硫酸浴によってア ノード酸化を行い，作製したアノード酸化皮膜を金属塩溶液 中にて電解し, 細孔内部に無機質コロイドを電析させ, 基板 を作製した。その後, SOL-GEL 法により酸化チタン膜の固定 化を行い光触媒活性について評価検討を行った。

\section{2. 実 験方法}

\section{1 アノード酸化皮膜の作製}

母材には純アルミニウム板 $(99.85 \%$ ）を使用した。前処理 としてメタノール脱脂拉よび $10 \%$ 水酸化ナトリウム水溶液で エッチングを行った後, 硝酸にてスマット除去を行い, ア ノード酸化皮膜を作製した。アノード酸化処理浴には $1.5 \mathrm{M}$ 硫酸溶液を使用し，浴温度 $10^{\circ} \mathrm{C}$ 一定，電流密度 $1 \mathrm{~A} / \mathrm{dm}^{2}$ ，電

*近畿大学理工学部応用化学科（† 577-8502 大阪府東大阪市小若江 3-4-1)。Department of Applied Chemistry, Faculty of Science \& Technology, Kinki University (3-4-1 Kowakae, Higashiosaka, Osaka 577-8502).

**近畿大学大学院生 (東大阪市)。Graduate Student, Kinki University (Higashiosaka, Osaka). 
Table 1 Electrolytic conditions of electrodepositing into $\mathrm{H}_{2} \mathrm{SO}_{4}$ films

\begin{tabular}{l|c|c}
\hline \hline Bath conditions & \multicolumn{1}{|c}{$\begin{array}{c}5 \times 10^{-3} \mathrm{M} \mathrm{SnSO}_{4} \\
10^{-2} \mathrm{M} \mathrm{H}_{2} \mathrm{SO}_{4} \\
5 \times 10^{-3} \mathrm{M} \\
\text { Benzenesulfuonic } \\
\text { acid } \\
10^{-2} \mathrm{M} \mathrm{H}_{3} \mathrm{BO}_{3}\end{array}$} \\
\hline Voltage & $\mathrm{MC} 30 \mathrm{~V} \mathrm{PtCl}_{6}$ & $\mathrm{AC} 15 \mathrm{~V}$ \\
\hline Electrolytic time & \multicolumn{2}{|c}{$10 \sim 60 \mathrm{~s}$} \\
\hline Bath temperature & \multicolumn{2}{|c}{$283 \mathrm{~K}$} \\
\hline Counter eld. & \multicolumn{2}{|c}{ Platinum plate } \\
\hline
\end{tabular}

Table 2 Composition of SOL-GEL solution

\begin{tabular}{l|c}
\hline \hline Methanol (solvent) & $50 \mathrm{ml}$ \\
\hline EDTA & $0.13 \mathrm{M}$ \\
Di-n-buthylamine & $0.14 \mathrm{M}$ \\
$\mathrm{H}_{2} \mathrm{O}_{2}$ & $1.30 \mathrm{M}$ \\
Titanium tetraisopropoxide & $0.13 \mathrm{M}$ \\
\hline
\end{tabular}

解時間 4 60 分の条件下で対極を白金板として直流定電流電 解を行った ${ }^{11), 12)}$ 。また，作製したアノード酸化皮膜は渦電流 式皮膜厚さ測定器（EDY-1000 (株サンコウ電子研究所製）を 用いて皮膜厚さを測定した。

\section{2 電解着色皮膜の作製}

作製したアノード酸化皮膜への電解着色は，白金およびす ずを対象として行った。白金の二次電解には, $10^{-3} \mathrm{M}$ 塩化白 金酸浴を用い，すずの二次電解には， $5.0 \times 10^{-2} \mathrm{M}$ 硫酸すずを 主成分とする混合浴を使用し, Table 1 の条件下で交流定電 圧電解を行った。

\section{3 酸化チタン膜の固定化}

酸化チタン膜は, SOL-GEL 法 ${ }^{13)}$ により固定化した。SOLGEL 溶液は, Table 2 に示した試薬を混合し, $65^{\circ} \mathrm{C}$ の湯浴中 で 5 分間加熱した後, 室温で放冷を行って作製した。この溶 液に，作製した白金およびすずによる電解着色皮膜を，それ ぞれ 1 分間浸漬および乾燥させた後, 電気炉 (FM-25 型 理

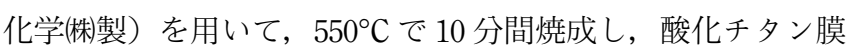
を固定化した（以後 $\mathrm{Pt} / \mathrm{TiO}_{2}$ 膜, $\mathrm{Sn} / \mathrm{TiO}_{2}$ 膜と表記）。また, 作製した三層皮膜のイメージ図を Fig. 1 に示す。

\section{$2.4 X$ 線光電子分析}

アルミニウム二次電解皮膜およびチタンの存在状態を調べ るために, X 線光電子分析装置 (ESCA-850 (株)島津製作所 製）によって解析した。

\section{5 酸化チタン膜の X 線回折法}

$450^{\circ} \mathrm{C}$ にて加熱処理後の酸化チタンの結晶型および電析し た金属の組成を調べるために，X 線回折装置（RINT2500 理 学電気(株製) によって解析した。

\subsection{ICP 発光分析法}

アノード酸化皮膜上に固定化された酸化チタン量および電 析した白金とすずの量を調べるために, ICP 発光分析装置

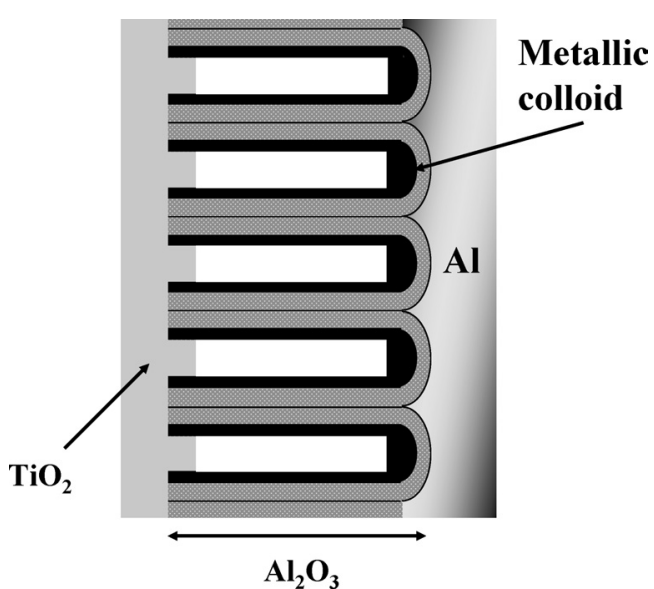

Fig. 1 Image of the cross section of prepared three layer film.

Table 3 Working conditions on decomposition of malachite green

\begin{tabular}{c|c}
\hline \hline Test piece size & $7.5 \times 7.5 \mathrm{~mm}$ \\
\hline Source of light & $\begin{array}{c}\text { Mercury-vapor lamp } \\
\left(0.3 \mathrm{mWcm}^{-2}\right)\end{array}$ \\
\hline $\begin{array}{c}\text { Distance from source } \\
\text { of light to test piece }\end{array}$ & $70 \mathrm{~cm}$ \\
\hline Volume of malachite green & $3 \mathrm{~cm}^{3}$ \\
\hline Adsorption time & $60 \mathrm{~min}^{-120 \mathrm{~min}}$ \\
\hline UV illumination time & $618 \mathrm{~nm}$ \\
\hline Wavelength & \\
\hline
\end{tabular}

（ICPS-7500 (柈島津製作所製）により定量を行った。

\section{7 表面粗さ測定}

酸化チタン膜を固定化した二次電解皮膜の表面粗さを，表 面形状測定器（DEKTAK3 日本真空技術(株製）により測定 した。縦横 5 回測定し, その近似值 3 点の平均值を表面粗さ とした。

\section{8 光触媒活性評価法}

二次電解により電析した白金およびすずの光触媒活性に対 する影響を検討するために，マラカイトグリーン（以下 $\mathrm{MG}$ と表記）の分解による簡易評価を行った。作製した皮膜

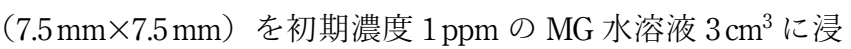
漬させ, 暗所にて 60 分間吸着後, 紫外線照射装置 (H-400A/ B 入江製作所(株)製）を用いて, Table 3 に示した光源条件 下で 120 分間紫外光を上方より照射し, $\mathrm{MG}$ の最大吸収波長 である $618 \mathrm{~nm}$ における吸光度を分光光度計（UV-200S (株)島 津製作所製）により測定した。一般的に, 光触媒能簡易評価 法としてメチレンブルーの分解による吸光光度法がよく用い られているが, メチレンブルーの光分解に対する安定性と測 定感度の両面で問題がある。すなわち MGのモル吸光係数 $(\varepsilon=154,809)$ はメチレンブルー $(\varepsilon=30,586)$ に比べて約 5 倍 の值を示すことより, 高感度の分析が可能である。したがっ て本法では MG 法を起用した。 


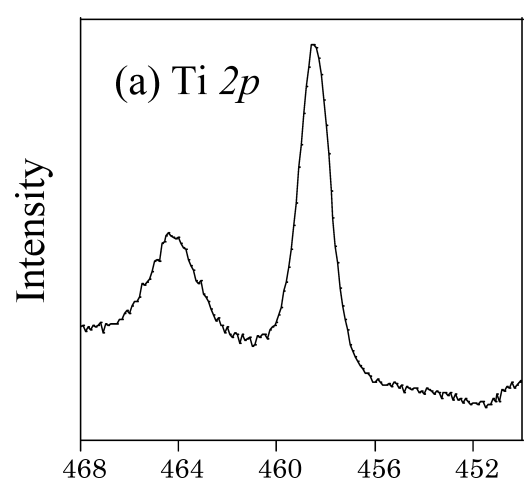

Binding energy $(\mathrm{eV})$

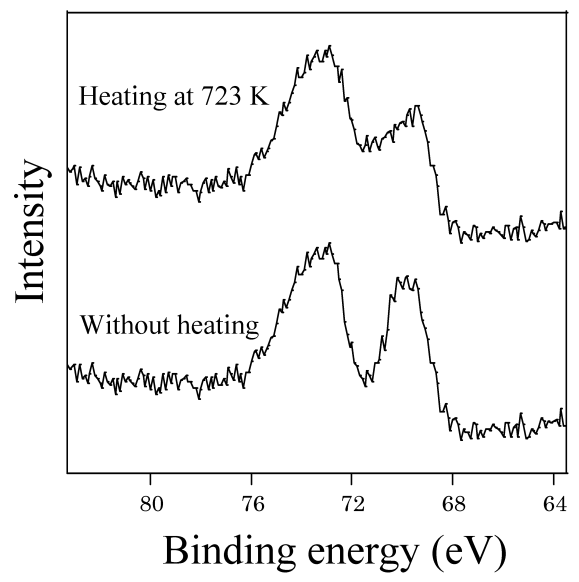

\section{9 透過型電子顕微鏡による断面観察}

電析した金属の孔中における状態を観察するために，透過 型電子顕微鏡（JEM-3010 日本電子データム(株製）により断 面観察を行った。試験片には純アルミニウム線（99.99\%）を 前項 2.1 および 2.2 と同様の操作を行い, 酸化チタンを固定化 したものを用いた。作製した試験片をエポキシ樹脂中に埋込 み，ミクロトーム（REICHERT ULTRCUTS ライカ(株)製）に より厚さ $20 \mathrm{~nm}$ に切断し, 加速電圧 $300 \mathrm{kV}$ の条件下で観察を 行った。

\section{3. 結果および考察}

\section{$3.1 X$ 線光電子分析結果}

3.1.1 チタンおよび酸素の $\mathrm{X}$ 線光電子分析結果

アノード酸化皮膜上に固定化した酸化チタン膜の X 線光電 子分析結果を Fig. 2 に示す。Ti 2 ス スペクトルにおいては, $459 \mathrm{eV}$ 付近に酸化チタンと思われるピークが現れ, XRD の結 果と合せて $\mathrm{TiO}_{2}$ として存在していることが示唆される。ま た，O 1s スペクトルでは， $530.5 \mathrm{eV} に ， \mathrm{TiO}_{2}$ を示すピークが 認められた。また, $533.5 \mathrm{eV}$ 付近に大きいピークが現れたこ とも確認できたが，これは $\mathrm{AlOOH}$ を示すピークであり，基 板であるアノード酸化皮膜に由来するものと考えられる。

\section{1 .2 電析した金属の X 線光電子分析結果}

電析した白金およびすずの X 線光電子分析結果を Fig. 3 に示す。その結果, 白金においては, 加熱前, 加熱後ともに 金属の白金と一致していることが確認できた。すずについて

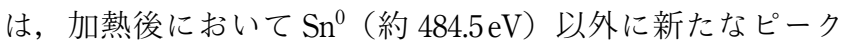

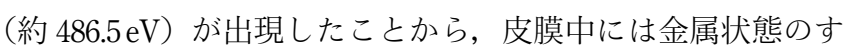

Fig. 2 XPS of the SOL-GEL $\mathrm{TiO}_{2}$ on anodized films.

Fig. 3 XPS of metallic colloids into anodized films.

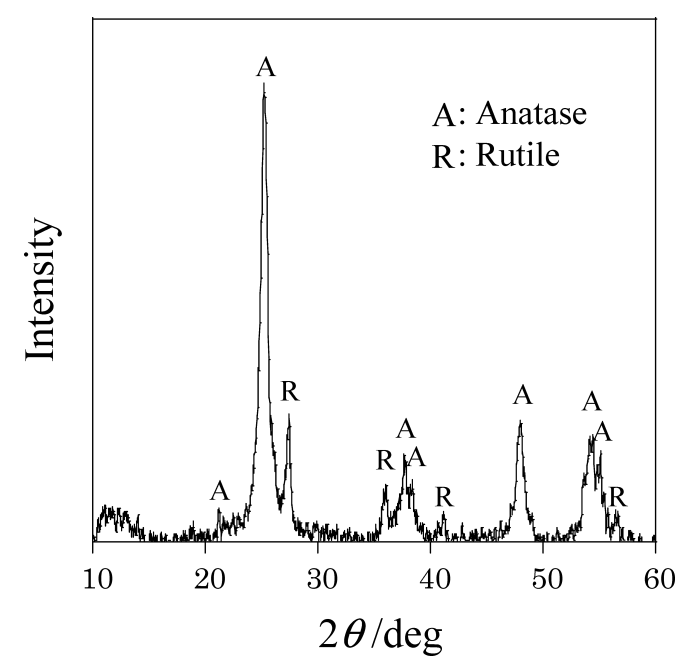

Fig. $4 \mathrm{XRD}$ patterns of the sol-gel $\mathrm{TiO}_{2}$ after sintering at $723 \mathrm{~K}$.

ずと 4 価あるいは 2 価のすず化合物が混在していると考えら れる。

\section{2 X線回折結果}

3.2 .1 酸化チタン膜の $\mathrm{X}$ 線回折結果

作製した酸化チタン薄膜の結晶型を調べるためにX 線回折 を行った結果を Fig. 4 に示す。その結果, SOL-GEL 法によ り作製した酸化チタン膜は, アナターゼ型とルチル型が混在 していることが確認できた。

3.2 .2 電析した白金およびすずの X 線回折結果

アノード酸化皮膜の細孔中に電析した白金およびすずの加 


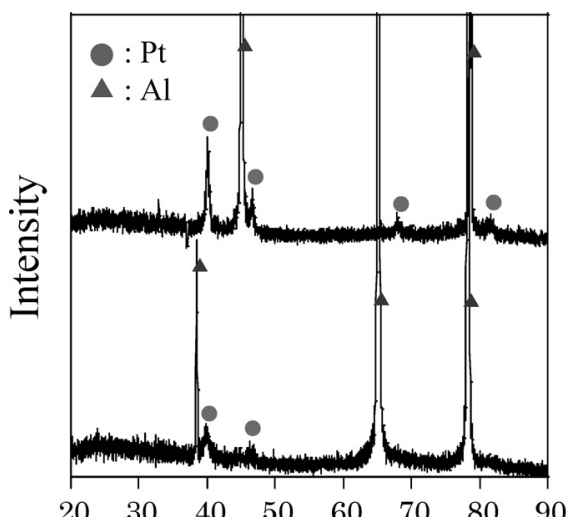

$\begin{array}{llllllll}20 & 30 & 40 & 50 & 60 & 70 & 80 & 90\end{array}$ $2 \theta / \operatorname{deg}$

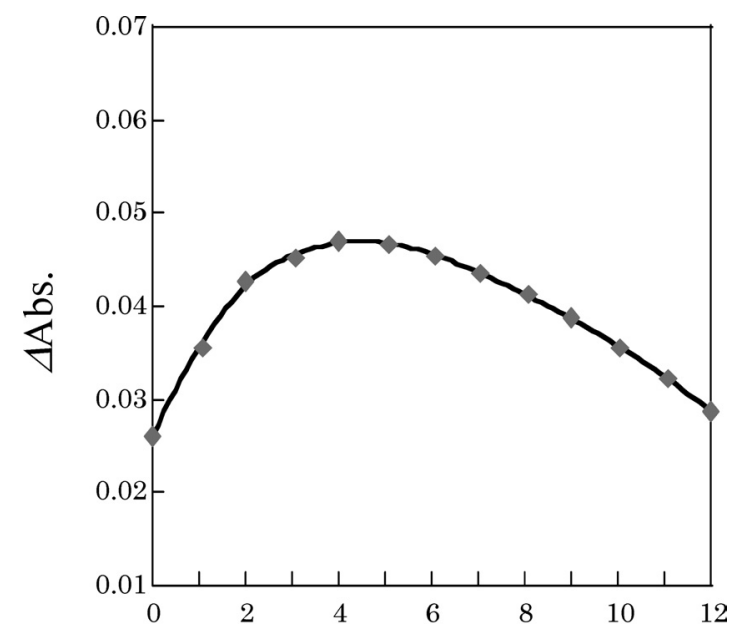

Film thickness $(\mu \mathrm{m})$

Fig. 6 Relationships between film thickness of anodizing films and photocatalytic activity.

熱前後におけるX 線回折結果を Fig. 5 に示す。その結果, 電 析した直後の白金およびすずはともに金属のピークを示して いることから金属の状態であることが確認できた。また， $450^{\circ} \mathrm{C}$ で加熱した後む金属の状態を保っていたが，すずに関 しては, ESCAによる分析結果から, 非晶質のすず化合物と 金属のすずが共存していると考えられる。

\section{3 光触媒活性評価による一次皮膜の膜厚の決定}

アノード酸化皮膜の膜厚の光触媒活性に対する影響を検討 した結果を Fig. 6 に示す。測定はアノード酸化皮膜の膜厚 $0 \sim 12 \mu \mathrm{m}$ の試験片を用いて行い, 紫外光照射開始から 60 分 後までの MG 吸光度を測定した。その結果, 膜厚が $4 \mu \mathrm{m}$ ま では光触媒活性は向上し, 膜厚が $4 \mu \mathrm{m}$ のときに最も高い活 性を示した。しかし，それ以上の膜厚になると活性は低下す る傾向が見られた。これは, 基板の比表面積, 固定化された 酸化チタン量およびアノード酸化皮膜中の不純物である硫酸 根に起因すると考えられる。皮膜中の硫酸根は, 膜厚の増大 とともに増加し, 酸化チタンに対して触媒毒として作用する ことが考慮されるため光触媒活性が低下したと考えられる。 すなわち, 膜厚 $5 \mu \mathrm{m}$ 以上で活性が低下した理由としては, 皮膜中の硫酸アニオン含有量に依存することが考えられる。 したがって, これ以降の実験には, 膜厚が $4 \mu \mathrm{m}$ のアノード 酸化皮膜を基板として用いた。
Fig. $5 \mathrm{XRD}$ patterns of metallic colloids into anodized films.

$2 \theta / \operatorname{deg}$

\subsection{ICP 発光分析結果}

二次電解時間の变化による白金およびすずの電析量と酸化 チタン量を調べるために, ICP 発光分析法により定量を行っ た結果を Fig. 7 に示す。アノード酸化皮膜の膜厚は $4 \mu \mathrm{m}$ と した。その結果，金属コロイドの電析量は，電解時間ととも に増加する傾向が見られた。ところが, 酸化チタン量は電析

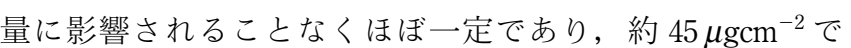
あった。したがって，電解時間による電析量の増加に伴い, 担持量が増加していると予想される。

\section{5 表面粗さと MG 吸着量の関係}

白金の電析量が異なる $\mathrm{Pt} / \mathrm{TiO}_{2}$ 膜の表面粗さ測定結果およ び MG 吸着試験結果を Fig. 8 に示す。その結果, 表面粗さの 值は, 白金の二次電解時間の増加とともに低下していること が確認できた。この原因としては, 二次電解浴中で電解研磨 されて皮膜が溶解し, 表面が平滑化したためと考えられる。 これはすずについても同様の傾向が認められた。また, 電解 時間が 10 秒の時点で表面粗さが大きく低下していることも 確認できた。MG 吸着能は, 測定条件として初期濃度を $2.5 \mathrm{ppm}$, 皮膜面積を $15 \times 15 \mathrm{~mm}^{2}$ とした。その結果, 表面粗 さとほぼ同じ傾向で吸着能が低下しており, 電解時間が 10 秒の時点で大きく低下していることがわかった。したがって， 表面粗さと吸着能には密接な相関関係があるものと考えられ る。

\section{6 光触媒活性評価結果}

\subsubsection{MG 吸光度の経時变化}

$M G$ 吸光度の経時変化を Fig. 9 に示す。その結果, 各皮膜 において吸光度変化に明らかな差が生じており, $\mathrm{Pt} / \mathrm{TiO}_{2}$ 膜が 最む光触媒活性を示すことがわかった。これは，白金がすず に比べて電子を吸着酸素に供与しやすいためと考えられる。

3.6.2 白金の電析量と光触媒活性の相関関係

金属コロイドの電析量が光触媒活性に与える影響を検討す るために, 光触媒活性を評価した結果を Fig. 10 に示す。そ の結果, $\mathrm{Pt} / \mathrm{TiO}_{2}$ 膜については, 電析量が増加するに従って光 触媒活性の著しい向上が確認され, 約 $3.1 \mu \mathrm{gcm}^{-2}$ で最も高い 活性を示した。このときのアノード酸化皮膜の色は，白金の 析出によってごく薄い黄色であったが，それ以上になると光 触媒活性は低下しはじめ, 約 $4.5 \mu \mathrm{gcm}^{-2}$ のとき, 白金の析出 量の増加によって黒色となり，二次電解を行っていないもの とほとんど変わらなかった。これは, 電析量の増加に伴って 白金が凝集しやすくなり, 電子 - 正孔の再結合中心になるた 


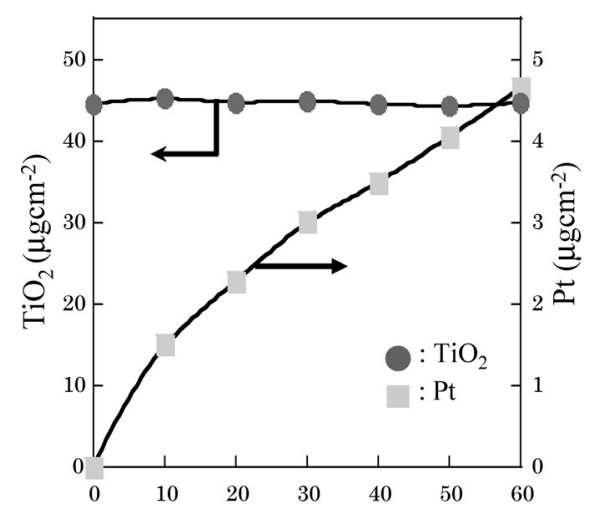

Electrolytic time (s)
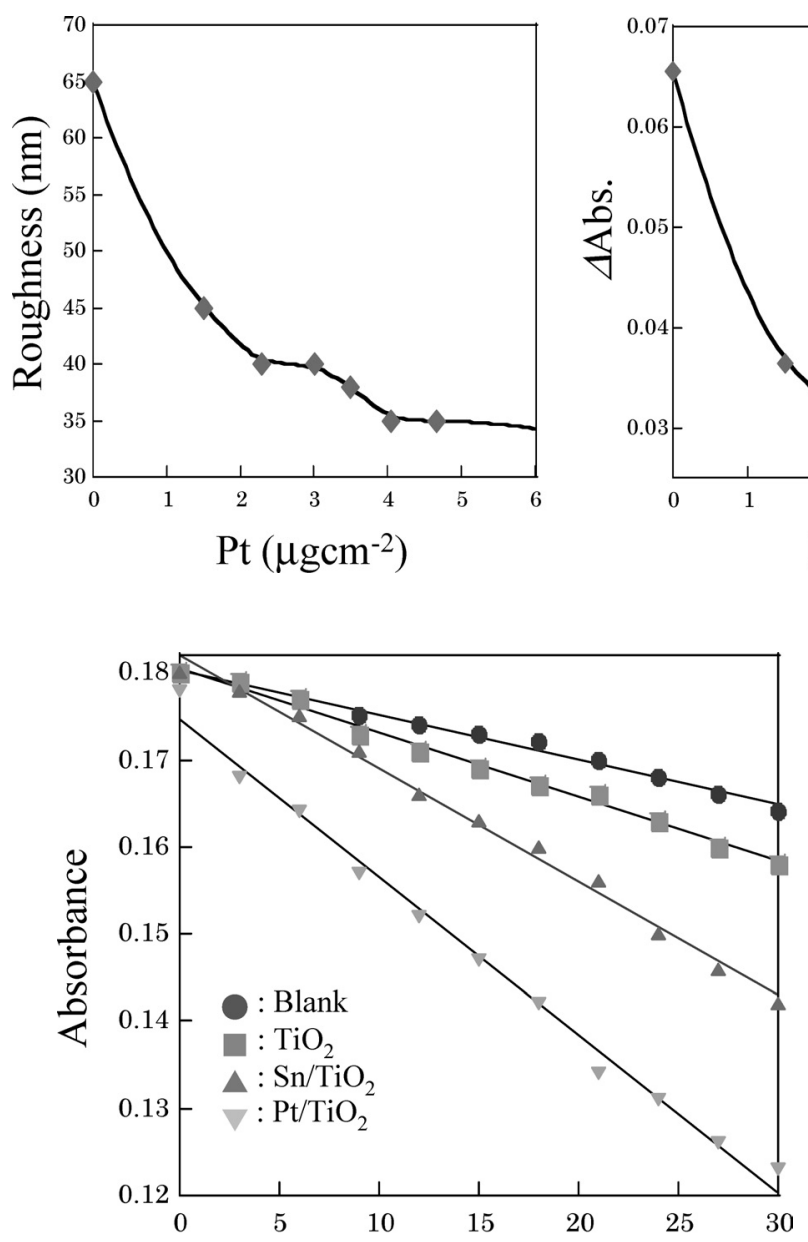

UV illumination time (min)

Fig. 9 Time course of absorbance of malachite green in $\mathrm{TiO}_{2}$ on anodized film.

めと考えられる。また, 電解研磨による比表面積の低下屯原 因の一つとして考えられる。反応物質の吸着量は分解量に影 響を与えると考えられるが，二次電解を施すことにより表面 積および $\mathrm{MG}$ 吸着量が減少していたことは前述した通りであ る。しかし実際には光触媒活性は向上していることから光触 媒活性は金属コロイドに大きく左右されたものと考えられる。

また, $\mathrm{Sn} / \mathrm{TiO}_{2}$ については, 白金と同様に電析量が増加す るに従って光触媒活性の向上が認められ, 約 $9 \mu \mathrm{gcm}^{-2}$ で最 屯高い活性を示した。 $\mathrm{Sn} / \mathrm{TiO}_{2}$ 膜においては, $\mathrm{Pt} / \mathrm{TiO}_{2}$ 膜に比
Fig. 7 Relationships between electrolytic time and the amount of metallic colloids.
Fig. 8 Plots of adsorption and surface roughness of $\mathrm{Pt} / \mathrm{TiO}_{2}$ films on anodized film. $\operatorname{Pt}\left(\mu \mathrm{gcm}^{-2}\right)$

$\operatorname{Sn}\left(\mu \mathrm{gcm}^{-2}\right)$

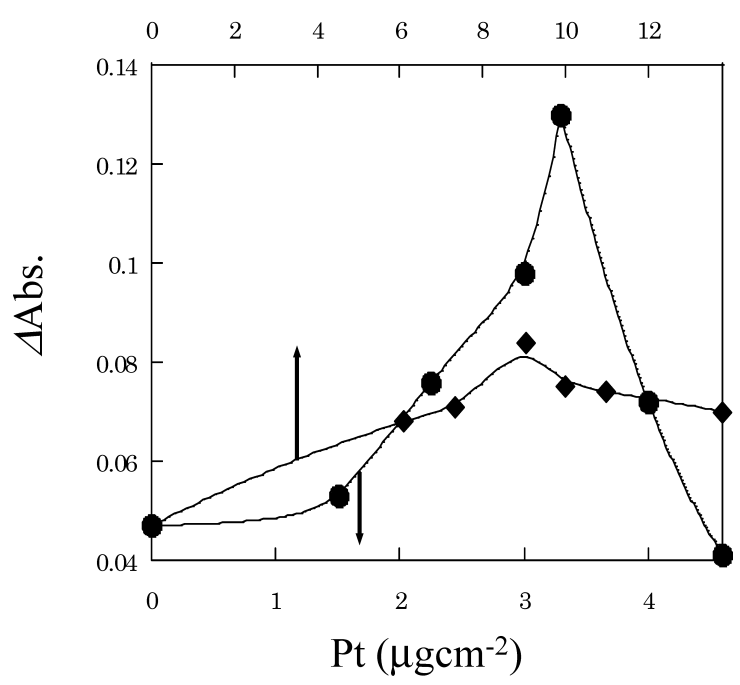

Fig. 10 Relationships between the amount of metallic colloid and photocatalytic activity.

べ低活性であったが，電析量が過剰になってもそれほど活性 は低下せず, 安定な值を示した。これは, 加熱されて酸化し たすずが紫外光によって酸化チタンとともに励起し, 酸化す ず側でもMG の分解反応が起こるためと考えられる。しかし, 酸化すずは非晶質であったため結晶の欠陥から電子 - 正孔対 の再結合を起こしやすいことから, $\mathrm{Pt} / \mathrm{TiO}_{2}$ 膜に比べて低活性 であったことも考慮される。また, 光触媒活性がわずかに低 下したのは，金属の状態で残ったすずが再結合中心になるた 


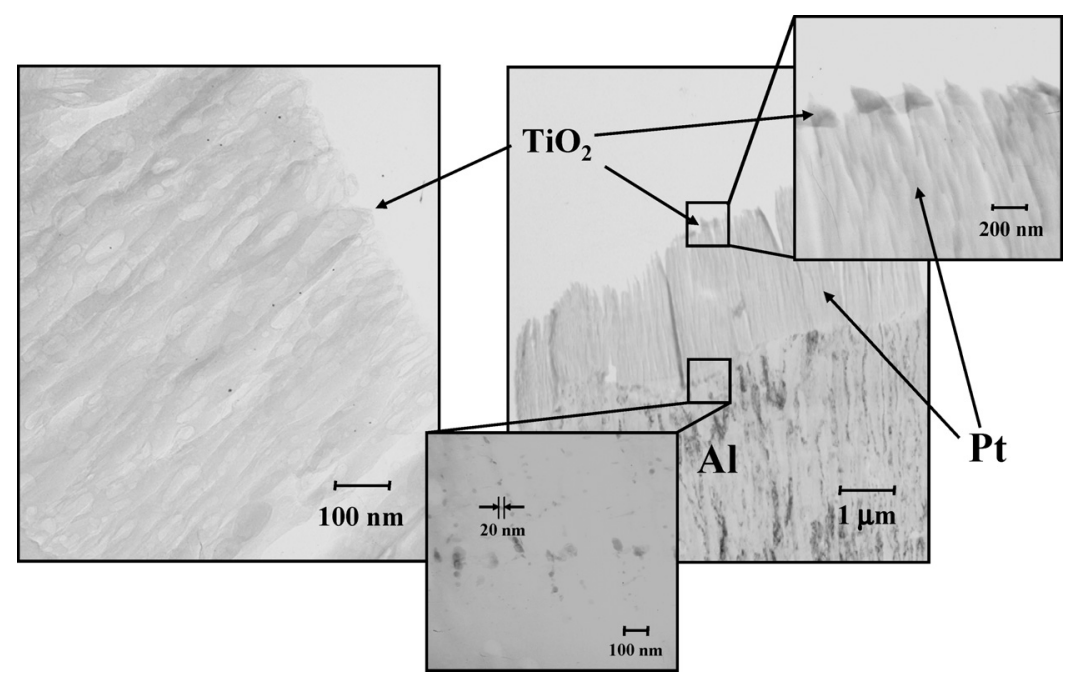

Fig. 11 Transmission electron micrographs of $\mathrm{TiO}_{2}$ on $\mathrm{H}_{2} \mathrm{SO}_{4}$ anodized films.

\section{めと考えられる。}

\section{7 TEM 観察結果}

透過型電子顕微鏡により断面観察を行った結果を Fig. 11 に示す。硫酸皮膜の孔径は約 $20 \mathrm{~nm}$ 程度で，電析金属の酸化 チタン膜への担持は加熱による表面への拡散で起こると考え られるが，電析量が多すぎる場合は金属が孔全体へ広がり， 電子一正孔の再結合を起こしやすい状態になると考えられる。 さらに, 界面の観察結果から, 金属コロイドの粒径は約 $20 \mathrm{~nm}$ であることがわかった。加熱により分散する金属の粒 径もそれに準ずると考えられる。したがって酸化チタン膜中 に存在する金属コロイドは極めて細かい微粒子であり,これ か影著に活性を向上させた最む大きな要因であると考えられ る。また，823K で焼成を行ったとき，皮膜に著しいクラッ クの発生が見られたが, $723 \mathrm{~K}$ のきはほとんど確認されな かったことから，硫酸皮膜を基板とするときは，焼成温度は $723 \mathrm{~K}$ が最も適していると考えられる。

\section{4. 結言}

硫酸皮膜を基板とした酸化チタン膜の光触媒活性を評価し た結果，以下のことが結論づけられた。

（1）光触媒膜の基板として, 電解着色皮膜を用いると電析 した金属コロイドが助触媒として働くため, 光触媒活性が向 上した。

（2）硫酸皮膜を用いた白金の二次電解皮膜では，電析した
白金が微粒子でしかも均一に分散して存在することにより， 光触媒活性の著しい向上が認められた。

(3) $\mathrm{Pt} / \mathrm{TiO}_{2}$ 膜において, 金属コロイドの電析量と光触媒活 性の関係を探求した結果, 白金自体が再結合中心之なり, 光 触媒活性の著しい低下が起こる原因も明らかとなった。

\section{参 考 文 献}

1）縄舟秀美, 石川俊輔, 水本省三, 清田 優 : 表面技術, 52 (2001), 354-356.

2) S. Bandyopadhyay and G. K. Sen: Advanced Drug Delivery Reviews, 17 (2002), 37-51.

3) L. Weng and S. N. B. Hodgson: J. Non-Crystalline Solids, 297 (2002), 18-25.

4) H. P. Beck, W. Eiser and R. Haberkorn: J. the European Cereamic Society, 21 (2001), 687-693

5) K. Kusakabe, K. Ichiki and S. Morooka: J. Membrane Science, 95 (1994), 171-177.

6）吉本哲夫：表面技術， 50 (1999)，242-246.

7）安保正一, 森実敏倫, 乾 智行, 加藤薰一, 野村英司, 咔田博 史：最新光触媒技術, エヌティーエス, (2000), 11-12.

8）山口靖英：表面技術，50（1999），256-259.

9）竹内浩士：表面技術，50 (1999), 260-264.

10）石崎有義：表面技術，50（1999），251-255.

11）藤野隆由, 奈良拓也：近畿アルミニウム表面処理研究会会誌, 216 (2002), $1-4$.

12）藤野隆由, 水本一, 野口駿雄: 軽金属, 48 (1998), 390-394.

13) M. Sato, H. Hara, T. Zishide and Y. Sawada: Journal of Materials Chemistry, 6 (1996), 1767-1770. 